\title{
Sustainable Innovation: Eco-development Tendencies and Theory of Communicative Action Standpoint
}

\author{
Dany Flávio Tonelli', Elizete Antunes Teixeira ${ }^{2}$,Vânia Aparecida Rezende Oliveira ${ }^{3}$, \\ Gideon Carvalho de Benedicto ${ }^{4}$
}

\begin{abstract}
The paper aims to show new production tendencies, trying to find out if they can be seen under a sustainable innovation perspective and if their logical action presents a connection to Habermas' Theory of Communicative Action. Considering the current innovation theories it is worth saying that specific approaches facing environmental sustainability are not common. Based on such scope, Industrial Ecology and Integrated Production Systems are highlighted. They are in the mainstream because they try to guide themselves not just by economic concerns, but also considering the articulation demand among different subjective and objective elements. The tendencies draw proposals to policies' transformations - regarding production methods - by placing economical, social and environmental dimensions in an inseparable way. However, even though after analyzing systems we did not identify any relation to the "Theory of Communicative Action", the habermasian approach is recognized as useful to innovation processes once achieved by consensus and mutual understanding.
\end{abstract}

Keywords: innovation; sustainability; theory of communicative action; integrated production systems; industrial ecology; public policy; science and technology studies.

'Federal University of Lavras - P.O. Box 3037 - Lavras - MG - Brazil. Zip Code: 37200-000. E-mail: danytonelli@dae.ufla.br ${ }^{2}$ Federal University of São João del Rey. E-mail: teixeiraelizete@yahoo.com.br

${ }^{3}$ Federal University of Lavras. E-mail: vrezende9@yahoo.com

${ }^{4}$ Federal University of Lavras. E-mail: gideon.benedicto@dae.ufla.br 


\section{Introduction}

The sustainability theme consists in one of the most important nowadays phenomenon. It means a challenge to production, without losing track of environmental eco-system's reloading capability (TONELLI et al., 2012). There is a large amount of actions that have been taken in order to develop production alternatives no longer aggressive to the environment and paired to economic wealth production and to society's common welfare. Many of them have been indicating such tendency. Some examples can be seeing in industrial ecology once increasing the use of alternative materials and electric power sources as well as by the waste's reuse in agro-ecology, a fact that reduces negative impacts over the environment and that achieves the replacement of external inputs by "Good Agricultural Practices". However, such transformation is linked to the development of new production technologies that valorize sustainability in its economic, social and environmental dimensions - in an inseparable way -, pointing towards to socio-technical changes, aiming to renew production processes. However, proposals focusing on environmental sustainability as sinequa non conditions are not as common.

The current paper aims to show new production tendencies, checking if they can be inserted in a sustainable innovation perspective and if its logical action presents some relation to the Habermas' Theory of Communicative Action. In order to elaborate the current essay, it was used a documental and bibliographic search methodology regarding tendencies as well as different theoretical approaches. Among the tendencies, Industrial Ecology and Integrated Production Systems were presented. Industrial ecology is the study of energy flow, materials and transformations. Integrated production is a system which produces food and other high quality products using natural resources and regulation mechanisms in order to avoid the use of polluting inputs and to ensure a sustainable agricultural production. Such systems are featured by an integrated and systemic view and by the development of alternative technologies created to fulfill specific contexts along with natural resources optimization, respecting social and environmental effects.

Firstly, the work discusses nowadays conceptions regarding innovation theories. Based on the economic perspective, innovation is focused on the instrumental sense of assets and wealth generation as well as on capitalism dynamics' perpetuation. Schumpeter and some of his followers have consolidated the idea that technical changes represent capitalism's reinvention by means of introducing new economic growth cycles allowed by it. Other conception - not less important - is inherited by social studies about science and technology that try to find ways of understanding social/collective dynamics based on the sense that innovation is organized by means of a network or a "seamless web" which adds distinct heterogeneous elements around itself. However, such conception is limited to act in a prescriptive way regarding methods' proposition, in opposition to the social technologies movement, which promotes both, a social inclusion political action and the participation in the development and use of proper technologies.

After the initial discussion, the paper explores the link between sustainable technologies and development. Based on a traditional economic growth viewpoint, the only growth limiting factor is technology. Under the sustainable development perspective, natural capital is irreplaceable, especially in respect to non-renewable resources. Even renewable resources' stocks and flows - although they are able to be replaced by technology's use - seem to be possible just if sustainable reposition rates of them are observed. So, the paper opens space to think about sustainable technologies, demonstrating production tendencies that look forward to join all inseparable demands coming from economic, social and environmental dimensions. By the end of it, the paper's final considerations bring back the stated issues in a reflexive way.

\section{Innovation approaches}

The innovation theory was quite marked by Economics influence. Schumpeter (196I), by searching for evidences in order to explain capitalism's supremacy over other possible economic organization systems, states that the secret to its perpetuation lays in its power to reinvent itself, by constantly introducing new economic growth cycles. New economic cycles would bring along the need to reorganize production by means of technological innovations. Thus, innovation would become an essential phenomenon without which economical stagnation would take place and, consequently, would take to the decline of main market laws that sustain the capitalist system (SCHUMPETER, 196I). Nelson and Winter (2005) state that practically all general contemporary studies about the capitalist machine are based on Joseph Schumpeter's book, "Capitalism, Socialism and Democracy". After that, many other economists presented their contributions following the same path which had been initiated by Schumpeter. Following such line, neo-schumpeterians such as: Nelson, Winter and others can be found. They all corroborate to the national innovation systems' approach (NELSON And Winter, 1977; Lundvall, 1988; Freeman, 1995).

According to Tonelli et al (20I2), approaches such as the "Innovation National Systems" hold: i) technical advance's nature (primarily, evolutionary); ii) how processes get an architecture structurally inserted, what involves specific contexts and conditions; iii) what are the strategies use to, among

ISSN: 07 I8-2724. (http://www.jotmi.org)

Journal of Technology Management \& Innovation (c) Universidad Alberto Hurtado, Facultad de Economía y Negocios. 
other things, develop wealth appropriation mechanisms and to deal with innovation complexity in the so called information era or knowledge era (NELSON And Winter, 1977; Lundvall, 1988; Freeman, 1995; Lundvall, 20I0).

There is another study field which is looking for understanding innovation processes as a socially inserted issue. It is the Sociology of Innovation. This approach counts on a great contribution from Social Studies on Science and Technology (BIJKER, Hughes Et Al., 1987; Law And Callon, 1992). The main concern does not lay on establishing the innovation economic impact, on finding out the obstacles to its spreading or on technologies transference, record institutional reforms or on investigating its effects over employment rates or over the countries' competitive capabilities. The main goal is to investigate innovation's social or collective production whereas immerse in relations and interrelations that build themselves around this particular issue (OLIVEIRA, 2008; Tonelli Et Al, 20I2). Economics takes social actors from an instrumental logic. It regards a kind of dehumanization of the years putting economic switches as an instrument of neutral mediation. Social studies on science and technology, particularly in the Actor-Web Theory, in opposition to economy, shows a sort of individual's rise to actor's status, humanizing objects and turning the exchange into a complex translational process (LATOUR, 2000; Law, 2003). Facing both approaches one can differentiate two distinct political purposes. The first, aims to perpetuate the schumpeterian idea of economic growth based on technological innovation development. The second disposes the impacts over economy and looks forward to understand innovation as a socially inserted practice of recruiting, combining and transferring distinct heterogeneous elements. Based on the first viewpoint, ecological systems sustainability yet does not put itself as an economic growth limiter. On the other hand, by the second view, there is no pre-set political proposition, besides, for example, ontological proposals such as the Actor-Web Theory, considering reality as a product from the hybridization between human actors and non human ones, through social-technical and heterogeneous webs.

Proposals focusing on the environmental sustainability matters are not usual. Social technologies movement, in Brazil, tries to hold such concern in a way to deal with inclusion issues. The Social Technology Institute Manual (ITS, 2007) holds a specific item discussing the following subject: "Socio-environmental and economic sustainability". Although the initiative is relevant, it is highlighted that the majority of production methods do not intend to produce social technologies. This particular approach is a quite specific one.According to the same institute, they are a set of techniques and transforming methodologies developed and/or applied to interact with the population and possessed by it, representing solutions to social inclusion and life conditions' im- provement (ITS, 2007). Taking such initial reflection as basis, it is possible to state that it is still mandatory to advance a lot in terms of creating values to sustainable innovation models, including in such scope - besides social innovations -, conventional innovations. It implies giving more importance - not just to the outcomes on economical innovations or on understanding its collective construction -, but also in its capacity to promote sustainability, especially the environmental one.

The appearing of innovation management collaborative models - that are not leaded just by economic and instrumental wards coming from the markets' side, as well as just by a descriptive side - aiming to understand social/collective phenomenon brings up the need to explore alternatives to promote the connection between comprehension and appropriate actions.

\section{Sustainable Development Perspective}

Sustainable development statements are related to the Brundtland Report (1987), in which it is said that sustainable development regards providing nowadays needs without jeopardize future generations' capacity to provide their own needs (BRUNDTLAND, 1987). According to Daly and Farley's (204) approach, development, in terms of sustainability, is expected to understand nature's limits and the development of policies allowing our economy to thrive inside such limits. Along with these restrictions there is an issue regarding the interaction of two complex systems: the human system and the ecological system which supports the first one. In order to picture the relation man/nature, Gladwin et al. (1995) categorizes three paradigms: Techno-centric paradigm, Eco-centric paradigm and the Sustain-centric paradigm. The first paradigm is the most prominent one and supports the idea that land is inert and passive, so it can be, legitimately explored. According to such approach, ethics is anthropocentric, selfish and useful because contemporary human beings are who really matter. So, all problems can be solved by means of technology.

The second paradigm promotes a vision over biosphere and society, based on holism's ecological principles such as: nature balance, diversity, ending limits and dynamic changes. Nature is fragile and vulnerable, so that is why - according to this perspective -, there is a pessimist view of technology, once one does not believe that human beings have the capacity to use it (technology) wisely.

The third perspective, Sustaincentric paradigm, defended by Gladwin et al. (1995) would embody a conciliatory and amplified sense due to different dimensions that are part of the sustainability sense. It is accepted that the global ecosystem is finite, vulnerable to human interferences and limited in 
its regeneration capabilities. Basically, such perspective tries to assess ecological, social and economic impacts from new technologies before they are actually introduced, aiming to minimize adverse effects.

The sustainable development idea translates development into a perspective of qualitative improvement regarding the capability to fulfill what is missing (needs and wishes) without quantitatively increase production, going beyond its loading environmental capabilities. Loading capability means the human population able to be supported by a certain ecosystem in a particular consumption level, using a given technology. The development means assets and services quality growth, as defined by its capacity to increase human welfare when provided by a certain production. A type of development which considers resilience - that is to say, a system's capacity to face disturbances, keeping its functions and structure based on a supportable ecosystem viewpoint (GLADWIN et. al, 1995; Daly And Farley, 2004;Veiga, 20 I0).

Growth, in its turn, based on the neo-classic theory, means a quantitative dimensional increase, or a production growth. Once, production is the flow of raw material and global ecosystem's through economic means, returning afterwards to nature as garbage. Based on such sense, it is stated that neo-classic economy is almost exclusively concerned with efficient attributions. Ecological economy also considers an important efficient attribution, which is also secondary, when compared to the scale and distribution. (DALY And Farley, 2004).

There is a paradigmatic duality on the growth approach due to the technological perspective. On the one hand, the ecosystem - seen as an extraction and economic linkage sector - supports the idea that even if such services become scarce, growth can remain forever because technology allows natural growth's return, by replacing natural capital by capital produced by men. Based on such perspective, the only limit to growth is technology and, given that one can always develop new technologies, there is no limit to economic growth. It is a weak sustainability conception. (WACKERNAGEL And Rees, 1996; Daly And Farley, 2004)

On the other hand, the strong sustainability builds up the assumption that natural capital is irreplaceable and, thus, essential. Strong sustainability defends natural capital maintenance, no matter human capital development forms, what means, it does not depend on an advanced technology. As definition, there is no sustainable consumption rate to non renewable resources. The main difficulty in using non renewable resources is not immediate exhaustion, but the techni$\mathrm{cal}$, economic, environmental and socio-political difficulties associated to resources' quality decrease and to the transition to substitutes. Renewable resources stocks and flows, although generated by nature, do not mean that human demands increase in biophysical environment happen in a sustainable rate. (HOLDREN, 1991; Wackernagel And Rees, 1995; Daily And Ehrlich, 1992).

A sustainable development does not limit the use of technology. New technologies can bring positive and negative effects. Technologies that increase resources' productivity can reduce the pressure over natural capital stocks. Technologies that increase manufactured capital and work's productivity frequently require processing a larger amount of resource's flow and, so, they tend to reduce resource's productivity. Historically, technological progress has been helping capital and work's productivity, by costs of resource productivity. Sustainable development takes this kind of technical progress to an opposite direction: a progress able to get more services per resource unit, rather than one which just uses more resources in order to operate the system (DALY and Farley, 2004).

Based on the sustainable development perspective, the relation between natural capital flow reservations and the services fund's resource represents one of the most important ecological economy concepts. Summarizing, production needs ecosystem structure's help. Ecosystem's structure produces the ecosystem's function which, in its turn, supplies services. All economic production has, thus, an impact over ecosystem's services and, once the impact is inevitable, it completely inserts itself in the core of the economic process (GEORGESCU-ROEGEN, 197I; Odum, 197I; Daly And Farley, 2004).

\section{Theory of Communicative Action Theory and Sustainable Innovation}

By being considered one of the biggest thinkers from the century, Jürgen Habermas aligned to Frankfurt School's thoughts - which has its theories spread throughout many scientific fields - developed one of the most discussed and known theoretical axes, the Theory of Communicative Action Theory. Regarding administration, it is worth highlighting that the theory has been a relation axis to all existing administrative theories. Vizeu (2005), based on different studies from the academic literature, shows that certain focuses given over Habermas' Theory of Communicative Action Theory offer a consistent explanatory basis to general behaviors. According to the author, the approach has been used, especially, due to traditional administrative theories' deficiencies and to more recent explanations about the organizations' phenomenon. Vizeu (2005) still underlines that the habermasian theory has been used in order to offer basis to the construction of opposite forms to the traditional managing model. Such movement happens because of organizations' emancipation issues. 
Such theoretical position defended by Habermas is substantiated by the critics on instrumental rationality. Therefore, according to Vizeu (2005), Habermas proposes that the Theory of Communicative Action might be an adequate referential in order to elaborate new rationality criteria, aiming to minimize contradictions on modern social organizations' form. In addition, he states - having the habermasian theory as basis - that the critic on instrumental reason becomes the critic on the bureaucratic model, in the sense that bureaucracy means a rational-instrumental ethos correction turning it into a self-sustained system.

Organizational world faces the functionalist position as a dominant one. By proposing an ideal model of interaction by language through which people socially organize themselves and look for an agreement, free from any external or internal imposition, it is possible to think of a search for conceptual models that connect innovation and sustainability by means of Habermas' Theory of Communicative Action Theory.

Habermas' theory places the basis to a kind of communication that aims to achieve mutual understanding. Habermas explains, through this theory that communication happens through language, between two or more individuals. An interesting point in such theoretical connection attempt is the habermasian consideration that the objective, the social and the subjective world embrace each other inside a communication process.

Based on such sense it is worth to highlight Vizeu's (2005) position.

"Due to the centrality of linguistic interaction in social praxis, Theory of Communicative Action is a construct which integrates multiple views of the world and of individuals, and such multiplicity is relevant to understand the organizational phenomenon. It allows verifying contradictions in interpersonal relations not often focused by organizational studies, once the idea of communicative distortion - before it becomes a mere organizational communication issue - reflects the difficulty of recognizing the other individual as a competent one, once he/she is a member of the same cultural community" (VIZEU, 2005, p.6 - translated from Portuguese).

Among the discussion about rationality processes, Gonçalvez (1999) shows that Habermas put himself radically against science and the universalization of techniques, what means that he goes against scientific and instrumental rationality penetration in decision spheres where another kind of rationality should reign: communicative rationality. Thus, the habermasian theoretical view holds that linguistic understanding is an interpretation cooperative process, where Theory of Communicative Action does not happen to search for results, but through a search for consensus and understanding.

Habermas' contribution promotes the possibility of a behavior change in contemporary society, looking forward to solve its conflicts, thus corroborating to Gonçalves (1999). Habermas visualizes the rescue of a communicative rationality in social interaction's decision taken spheres that were penetrated by an instrumental rationality. According to the author, given that men does not simply react to environmental stimulus, but give a meaning to their actions and, thanks to language, they are also able to communicate perceptions and desires, intentions, expectations and thoughts. Habermas foresees the possibility of, by means of dialogue, having men back to their role as individuals.

\section{Production tendencies in the sustainable innovation perspective}

\section{Industrial Ecology}

Conventional production methods, quite intense in terms of renewable and non-renewable resources, once, most of the time, are damaging the environment - due to negative externalities - cause unbalance in ecosystems, a fact that takes to questioning the effectiveness of such methods. So, the 70's mark the milestone of the so used term Industrial Ecology, initially coined in industrialized countries like Japan and United States. According to Frosch (1992) the idea of Industrial Ecology is based on a direct analogy to natural ecological systems, where there is natural waste's consumption and loss, a fact that, according to Allenby (1992), also refers to interrelation's sustainability maintenance between human and economic environment.

Hileman (1992) conceptualizes Industrial Ecology as being the study of land's organization forms as well as of production methods aiming to find protection to human beings, ecosystems and future generations' health. Therefore, the compatibility among companies' goals, technological development and wealth creation is something plausible inside an environmental perspective which tries to find ways to avoid further environmental mistakes (TIBBS, 1993) and which considers the current moment as a transitional situation due to a social sustainability paradigm (SPETH, 1992).

According to Garner and Keoleian, (1995) yet there is not an unique definition to Industrial Ecology, but they all have some similar attributes to the systemic vision and the relation among systems, the energy flow studies, materials and transformations; to multidisciplinary approaches; to an orientation concerned to the future; to change considerations of linear and open processes into cyclic and closed; to an effort to reduce the impact of industrial systems over eco-

ISSN: 07 I8-2724. (http://www.jotmi.org)

Journal of Technology Management \& Innovation (c) Universidad Alberto Hurtado, Facultad de Economía y Negocios. 
logical systems and to the harmonious relations between these two systems.

Industrial Ecology and Industrial Metabolism to the Clean Technologies National Center - CNTL (SENAI, 2003), and Tibbs (1993), both are concepts linked to new industrial production patterns and are deeply related to a clearer production concept. There are six main elements in Industrial/ Industrial Metabolism Ecology:

I. Creating industrial ecosystems: maximizing the production use of recycled materials, optimizing the use of materials and electrical power, minimizing disposal generation and revaluating disposals as raw material to other processes.

2. Matching inputs and outputs of industrial processes to ecosystems natural capacities: understanding the capacity of the great natural systems to observe toxic disposals, or other kinds, in typical situations or environmental disasters. 3. Dematerialization: reducing the intensity regarding the use of materials and electrical power in industrial production.

4. Improve industrial processes metabolic ways due to materials use: reducing or simplifying industrial processes so they can emulate highly efficient natural processes.

5. Systemic patterns in electric power use: promoting the development of power supply systems that work as part of the industrial ecosystem and that are free from negative environmental impacts to current patterns regarding energy use.

6. Policies' alignment to the long term industrial system evolution perspectives: nations acting together, aiming to integrate their economic and environmental policies. (CNTL, 2003).

Roberts (2004) presents as Industrial Ecology principles the development of partnership deals with other companies, government and other social organizations looking forward to develop sustainable environmental practices. He also highlights industry's geographically concentrated location role as a factor which positively contributes to sub-products concentration, materials flow and electric power excesses in a way to systematize the use and reuse of raw materials and electric power systems. According to the author, institutional structures must be developed allowing process' boost regarding actions meeting Industrial Ecology, in a way to spread and demonstrate benefits and advantages inherent to productive processes inside such perspective. Still, according to Roberts (2004), Industrial Ecology can be applied to eco-industry by means of the development of three levels: in terms of company level, in eco-industrial plants context and web systems.

\section{Integrated Production System}

Lately, one can see an increasing world demand for safe production, aiming to achieve minimum negative impact to the environment, requesting agrochemicals reduction, facing protected workers and consumers. Besides adopting competitiveness, sustainability and traceability principles; there is a growing need to rethink innovative and efficient cultural behavior changes, in order to replace conventional production practices (GLIESSMAN, 200 I;Altieri, 2009).

Based on such context, there are national and international rules that take aspects related to products and production processes' safety and quality aspects into consideration. Such rules come from efforts done by governments and public agents as well as by private agents from the food products market. They were defined in order to ensure feeding safety, following new consumers' requirement patterns.

European Union countries such as Spain, France, Italy and others, supported by International Organization for Biological and Integrated Control of Noxious Animals and Plants - IOBC/WPRS guidelines, developed, during the 70's, the concept of Integrated Production (IP), aiming to cover consumers and distributers chain requirements, looking for healthy food without agrochemicals, environmentally correct and socially fare, motivated by actions taken by consumers defense (ANDRIGUETO, et al., 2009).

The integrated production system's forerunners in the European Community were Germany, Switzerland and Spain. They had already initiated the process because of the need to replace expensive conventional practices by an integrated production system which reduces production costs, and improves products/services' quality and safety, facing social responsibility and reducing environmental damage.

Integrated production's definition and goals were created on March 6th, 1992, in Wadenswill - Switzerland, by means of a cooperation agreement between IOBC/WPRS.

"Integrated Production is a farming system that produces high quality food and other products by using natural resources and regulating mechanisms to replace polluting inputs and to secure sustainable farming. Emphasis is placed on a holistic systems approach involving the entire farm as a basic unit, on the central role of agro-ecosystems, on balanced nutrient cycles and on the welfare of all species in animal husbandry. The preservation and improvement of soil fertility and of a diversified environment are essential components. Biological, technical and chemical methods are balanced carefully taking into account the protection of the environment, profitability and social requirements (IOBC, 20I0)." 
Integrated Production concept comes from the evolution of plant protection methods which passed through many changes along the last decades. The evolution of such methods is linked to efforts done by IOBC aiming to develop, improve and apply biological control techniques to agricultural production, in a way to make it sustainable from an environmental and social viewpoint, and also feasible, from an economic viewpoint.

Developing and implementing basic technologies in ecosystems in order to protect plants has been some of IOBC's main goals since its foundation in 1956. The evolution of biological control concepts evolution for Integrated Pest Management (IPM) and, finally, for a holistic response approach was certainly not accidental. Unlike, it was a logical answer to scientific patterns and concepts development progress, they have been important for IOBC's background.

Integrated Production advocates for good agricultural practices (BPA) preserving and increasing soil fertility and environmental diversity. Biological, technical and chemical controls are carefully balanced, considering environment protection, aiming for an economic feasibility and respecting social matters (ZAMBOLIM, et al., 2003). Thus, food and other produced products in such system are traced. Traceability means the capacity to find the production process background and to locate and use a product by means of a registered identification, allowing the response to consumer's interests on produced products safety, in terms of quality and the awareness of environment preservation needs, workers welfare and society in general (ZAMBOLIM, et al., 2003).
The certification can be inherent to the production method, to product's quality and to regional origins, demanding highlights on evidences regarding good practices appliance, technical rules and codes of conduct with their proper controls and guaranties, ensuring the certification bureau's program trustworthiness, producer's spontaneous inclusion and consumer's trust in the market.

Regarding Integrated Production, traceability is an important aspect due to post-harvest handling. Traceability is defined as the capacity to meet location background and the use of products or batches, by means of unique registered identification. The system which integrates this unique identification and the location and use background is called Product Traceability System. Traceability is a tool in service to food's quality and safety, but once isolated, does not ensure its quality or safety.A quality food must be necessarily safe and, so, traceable. (CANTILLANO;Almeida, 2009)

According to Andrigueto, et al., (2009); Portocarrero and Kososki (2009) Integrated Production has as its principle - since its conception - a systemic view, first focusing on an integrated pest handling, going to the integration of processes in all the production chain. Therefore, its implementation must be seeing in a holistic way, as shown in Figure I, a structure laying over four supporting pillars: productive based organization, system's sustainability as well as components that integrate and consolidate other processes.

In order to achieve a Safe Food Policy, according to Portocarrero and Kososki (2009) and in accordance to Figure 2, it is imperative - in first place - establishing such policy main

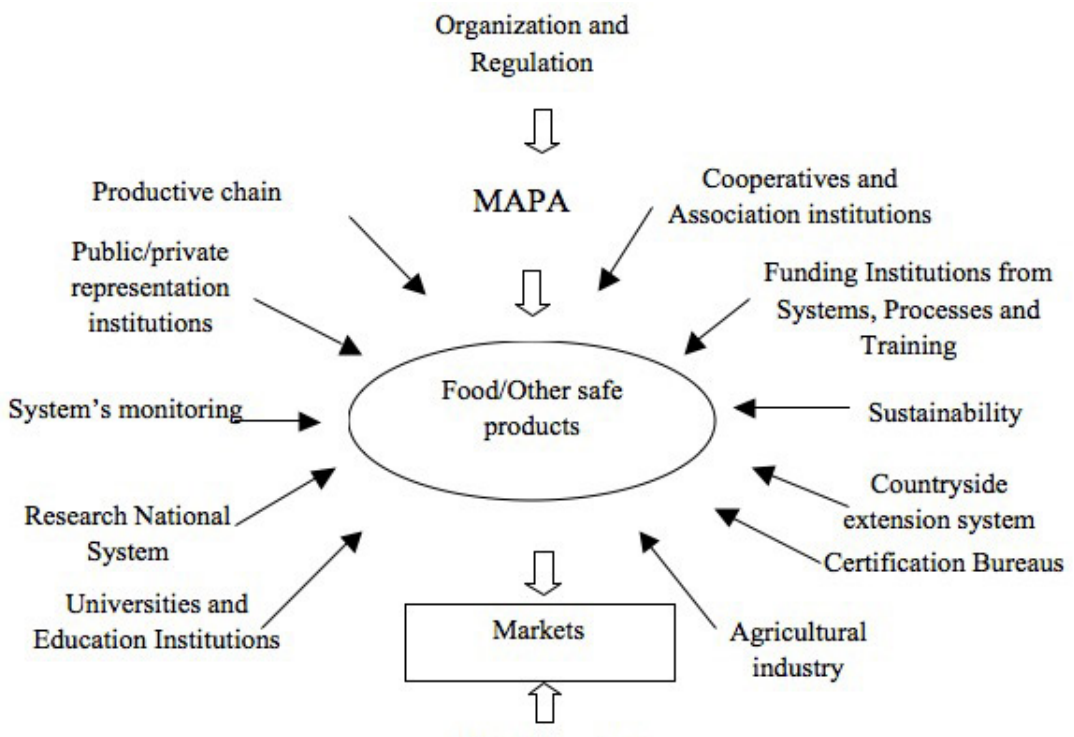

Final Product

Figure I. Integrated Production System's organization and regulation. Source:Andrigueto, et al., (2009); Portocarrero and Kososki (2009)

ISSN: 07 I8-2724. (http://www.jotmi.org)

Journal of Technology Management \& Innovation @ Universidad Alberto Hurtado, Facultad de Economía y Negocios. 
goals: plans' organization, programs, systems, projects and institutional instruments; under a unique public policy control, developed to obtain safe food, what means fulfilling sanitary, technological, environmental and social requirements, matching procedures to international quality demands and the support to Brazilian agricultural productive chains.

So, implementing policies heading to food's value aggregation, to quality production and other commercialized products based on management, to quality and safety models, to sustainability, to procedures monitoring agricultural practices and traceability methods, in all the steps - since input acquisition up to offering the product to final costumers - is one of the public policies' targets due to a sustainable agriculture.

The legal milestone to Agricultural Integrated Production in Brazil (IP Brazil) was set by Normative Instruction \#27, which validates Specific Technical Rules in order to get official certification stamps for animal and vegetable origin products. The system started with Fruits Integrated Production, in 200I, and was coordinated by Agriculture, Cattle Raising and Supply Ministry (MAPA) along with public and private partnerships (Normative Instruction, \#27, MAPA, 2010).

\section{Interactions among the presented methods, Sustainability and Theory of Communicative Action}

Theoretical-methodological assumptions from the exemplified production tendencies, are built based on systemic and integrated approach arguments, that aim to rationalize the use of natural resources, a stronger productive efficiency reducing the use of raw materials, electric power and water as well as reducing or reusing disposals. However, the concerns regarding world rules following, environmental legislations and "green consumers" requirements are prominent. Although they seem to be closed methods imposed from top to bottom, it does not disqualify them as eco-development conceptions, once they look forward to integrate economic, social and environmental dimensions in inseparable forms.

Theory of Communicative Action Theory reveals itself as a quite useful framework to Innovation Theory due to the sustainability perspective. However, it becomes a crucial alert to the fact that the current essay's proposed discussion did not have the intention to present a mechanic and empiric application of Habermas' theory but actually has it as the sustainability pillar inside a debate in which theoretical substantiation and connection elements are sought in order to substantiate a relation among different subjects.

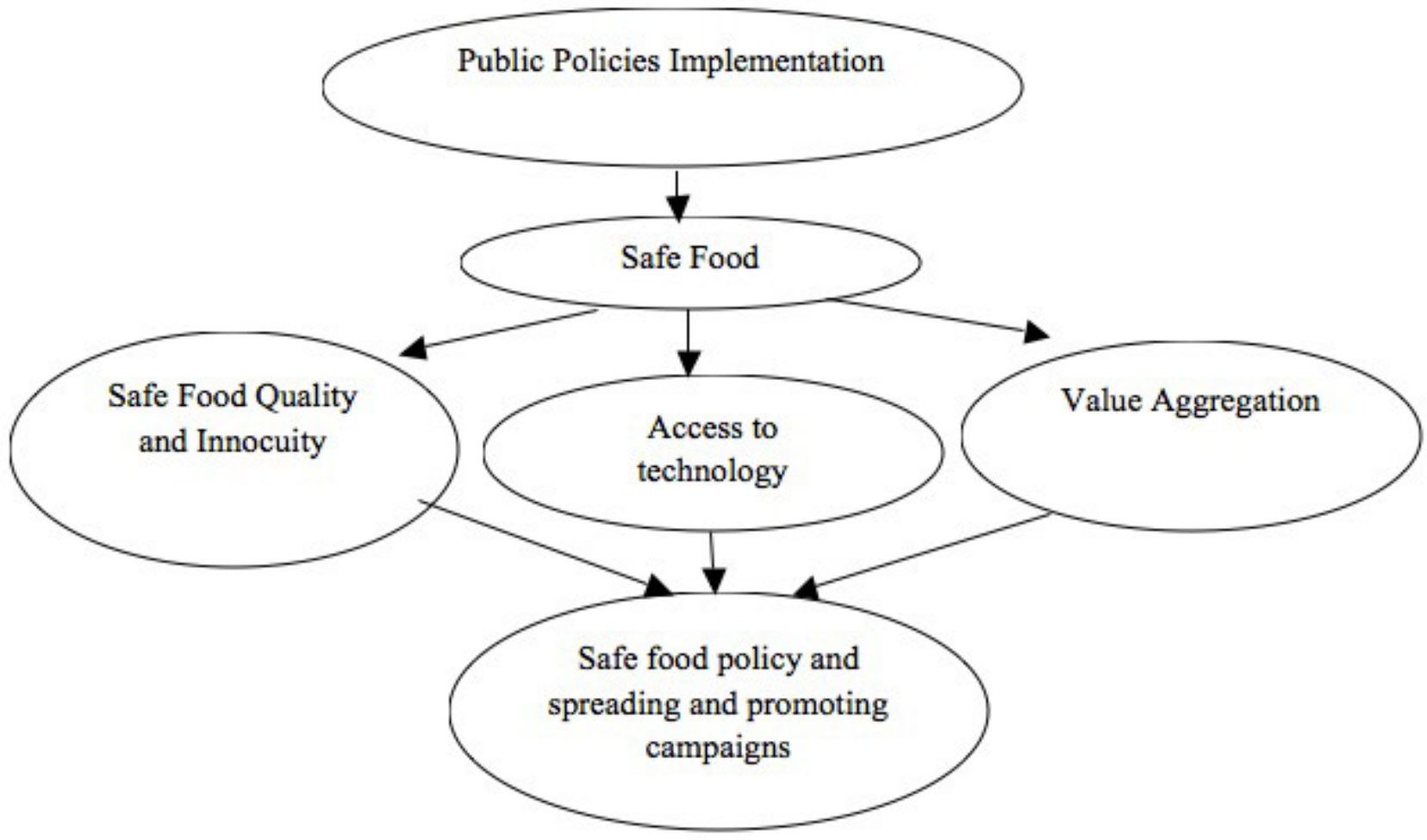

Figure 2 Public Policies Process for food and other safe products. Source: Portocarrero and Kososki (2009)

ISSN: 07 I8-2724. (http://www.jotmi.org)

Journal of Technology Management \& Innovation (c) Universidad Alberto Hurtado, Facultad de Economía y Negocios. 
By contextualizing the two production tendencies discussed in the current work, it is possible to state that the Industrial Ecology was introduced in a system which had its development sustained by a mechanical and economic view. Therefore, modernization - which has been prominent in industrial society - faced instrumental rationality as a dominant factor. Based in such sense, Habermas questions this kind of process which advocates for a definition on unilateral strategies in order to reach efficient results. By means of Habermas' position it is possible to go against the domination of instrumental rationality. According to him, communicative rationality must be found in decision taking spheres that were dominant before, by means of a radically instrumental position. It demands a transformation over the technique which rules procedures for a technique which comes from a conjunct and negotiated construction among the most diverse actors.

Industrial Ecology, by stating men-nature relation's shortage - where a systemic and dialogic view must prevail walks through the theoretical assumptions of the Theory of Communicative Action Theory. According to Habermas (1987) social rules are developed by individuals coexistence in which an interaction among them takes place and where Theory of Communicative Action consequently appears representing the expectations from the involved ones.

The idea extracted from Habermas (1987) shows that the capitalist system and the productive forms developed with scientific and technical knowledge growth started to privilege companies as decision taking spots that, so far, were prominent in the social sphere. It's worth saying that literature, by indicating that the Industrial Ecology provides a debating way among the triad state-market-society, puts itself - at least in discourses level - in consonance to the habermasian thought, which shows that an instrumental position by itself does not privilege rules making considering social, ethical and many other aspects discussed in the social sphere.

Gonçalves' (1999) quote cited bellow clearly shows the aforementioned problem.

The cause of the modern industrial society's serious problems, according to Habermas, does not lay on the scientific and technological development themselves, but, actually, on such perspective's sidedness as a human project, which puts aside the discussion regarding vital matters around whom a society decides the directions of its history. Individual's subjectivity is not built through a self-reflection lonely act, but, actually, is the result of a process which happens in a complex interaction web. Social interaction is, at least potentially, a dialogical and communicative interaction, once it produces the Theory of Communicative Action deflation by reducing it into its own action structure, which generated, in contemporary men, ways of feeling, thinking and acting - all substantiated by individualism, isolation, competition, calculation and incomes -, that are on the basis of social matters. (GONÇALVES, 1999, p. 130-13 - translated from Portuguese)

By taking the second tendency discussed in the present paper into debate, it means, the Integrated Production System where the use of natural resources is optimized aiming for a sustainable agricultural production, it is possible to state that the search for a socially fare model is implicit in such development assumption. Think about agricultural technology in the aforementioned bias shows that the habermasian thought - which defends a Theory of Communicative Action aiming for a dialogue - allows individuals involved with it to establish a discourse interchange that can take to the articulation of an eco-development which minimizes non desirable future consequences. Inside a socio-dimensional analysis, such position considers socio-economic effects in a society where a communicative reasoning demands more attention. Developing a critical and argumentative sense of individual is one of the points found among Habermas' thoughts and the production tendencies in the eco-sustainable view.

\section{Final Considerations}

Investigated tendencies present a significant disruption regarding traditional production methods, in order to valorize environmental perspectives. On the other hand, it is not possible to state - especially considering the social field that they have some relation to the habermasian perspective. Even though representing a large advance in relation to the conventional view, the integration among environmental, social and economic elements end up being a contingence yet managed in accordance to an instrumental logic, once tendencies are summarized as a set of techniques conceived in a place where there is no full participation of all involved actors. It disqualifies participative construction in term of mutual understanding.

Theory of Communicative Action Theory advocates that the positivist vision and its precepts must be questioned. It also assumes that it is possible to achieve a social transformation by means of places promoting communication, all developed in order to avoid that only unilateral strategies views are privileged. Meantime, it is worth stating that the dialogicity proposed by Habermas' theory helps the discussion about a Sustainable Innovation and the tendencies to eco-development. By standing for the urgency on the formation of critical and participative individuals - in which a Theory of Communicative Action enables the development of rules that shorten the distance between the dichotomy objectivity-subjectivity -, Habermas allows a debate ena-

ISSN: 07 I8-2724. (http://www.jotmi.org) 
bling production methods thinking, all laying over a relation where industrial systems reorganization does not take to the idea that resources and disposals are extremes on a destructive relation.

One of the current limitations lays on the fact that it is based on theoretical constructs, but not on empiric studies which directly regard to the practices of people inserted in these production tendencies and the logic that drives their action. It also opens way to explore new studies that aim to align innovation, sustainability and Theory of Communicative Action themes.

\section{References}

ALLENBY, B. R. (1992) Achieving Sustainable Development Through Industrial Ecology. International Environmental Affairs. 4(I), 56-68.

ALTIERI, M. (2009) Agroecologia: a dinâmica produtiva da agricultura sustentável. 5th ed. Ed. da UFRGS, Porto Alegre.

ANDRIGUETO, J.R; Nasser, L.c.b; Teixeira, J.m.a; Simon, R.f; Martins, M.v. De M; Kososki, A.r. (2009) Produção Integrada De Frutas E Sistema Agropecuário de produção integrada no Brasil. In: Brasil. Ministério da Agricultura, Pecuária e Abastecimento. Produção Integrada no Brasil:Agropecuária Sustentável, Alimentos Seguros. Mapa/ACS, Brasília.

BIJKER,W. E. et al. (1987) The Social construction of technological systems: new directions in the sociology and history of technology. Cambridge, Mass.: MIT Press.

BRUNDTLAND, G. (1987) World Commission on Environment and Development. Our Common Future. Oxford, Oxford University Press.

BUEN, JØRUND. (200I) Industrial ecology - only needed in the north? International Journal of Economic Development. $3(2), 1-50$.

CANTILLANO, R. F. F.; Almeida, G.V. B. De (2009) Manejo e logística na colheita e pós-colheita na produção integrada de frutas no Brasil. In: Brasil. Ministério da Agricultura, Pecuária e Abastecimento. Produção Integrada no Brasil: Agropecuária Sustentável Alimentos Seguros. Mapa/ACS, Brasília.

DAGNINO, R. (2004)A tecnologia social e seus desafios. In: FUNDAÇÃOBANCODOBRASIL (Ed.). Tecnologia Social: uma estratégia para o desenvolvimento. 14, Rio de Janeiro, I87-210.
DAILY, G.C.; Ehrlich, P.r. (1992) Population, Sustainability, and Earth's Carrying Capacity:A Framework for estimating population size and lifestyles that could be sustained without undermining future generations. BioScience, 42, 76I-77I.

DALY, Herman; FARLEY, Joshua. (2004) Economia ecológica: princípios e aplicações. Trad. Instituto Piaget; Lisboa.

FREEMAN, C. (1995) The National System of Innovation in historical perspective. Cambridge Journal of Economics [S.I.], I9(19), 5-24.

FROSCH, R. A. (1992) Industrial ecology: a philosophical introduction. Proceedings of the National Academy of Sciences of the United State, 3, 800-803.

GARNER, A.; Keoleian, G. (1995) Industrial Ecology:An Introduction. School Of Natural Resources and Environment, and NPPC Research Manager. University of Michigan. East University.

GEORGESCU-ROEGEN, N. (197I) The Entropy Law and the Economic Process. Cambridge (EUA): Harvard University Press.

GLADWIN, Thomas N.; Kennelly, James J.; Krause, TaraShelomith.Shifting (1995) Paradigms for sustainable development: implications for management theory and research. Academy of Management Review. 20(4), 874-907.

GLIESSMAN, Stephen R. (200I) Agroecologia: processos ecológicos em agricultura sustentável. $2^{\mathrm{a}} \mathrm{ed}$. Ed. Universidade/UFRGS, Porto Alegre.

GONÇALVES, Maria Augusta Salin. (1999) Teoria da ação comunicativa de Habermas: possiblidades de uma ação educativa de cunho interdisciplinar na escola. Educação e Sociedade, São Leopoldo, 66, I25-I 40.

HABERMAS, J. (1987) Teoria de la acción comunicativa IRacionalidad de la acción y racionalización social. Madri: Taurus.

HILEMAN, B. (1992) Industrial ecology route to slow global change proposed. Chemical \& Engineering News, 70(34), 7-I4.

HOLDREN, J. P. (I99I) Population and the energy problem. Population Environment. 12, 23 I- 255.

BC (2010) International Organization for Biological Control of Noxious Animals and Plants. Integrated Production in Europe. Disponível em:<http://www.iobc-global.org/>.Acesso em: 02 de dez. de 2010.

ISSN: 07I 8-2724. (http://www.jotmi.org) 
ITS. (2007)Conhecimento e Cidadania I: tecnologia social. In: INSTITUTO DE TECNOLOGIA SOCIAL. São Paulo: ITS Brasil, 2007.

LATOUR, B. (2000) Ciência em Ação: como seguir cientistas e engenheiros sociedade afora. São Paulo: Unesp, 2000.

LAW, J. (2003) Traduction/Trahison: Notes on ANT. Centre for Science Studies, p.I-15. Available at: <http://www.lancaster.ac.uk/fass/sociology/papers/law-traduction-trahison. pdf $>$.Accessed on: May, I3th - 2009.

LAW, J.; Callon, M. (1992) The life and death of an aircraft: a network analysis of technical change. In: BIJKER,W. E.; LAW, J. (Ed.). Shaping technology/building society : studies in sociotechnical change. Cambridge, Mass.: MIT Press, pp. 21-52.

LUNDVALL, B. A. (1988) Innovation as an interactive process: from user-producer interaction to the national system of innovation. In: DOSI, G. et al (Ed.). Technical Change and Economic Theory. London: Pinter Publishers, pp. 349-369.

LUNDVALL, B.-Å.(20I0) Introduction. In: LUNDVALL, B.-Å. (Ed.). National Systems of Innovation: toward a theory of innovation and interactive learning. London: Anthem Press, Cap. I, pp. I-22.

MAPA (2010) Ministério da Agricultura, Pecuária e Abastecimento. Produção Integrada. Available at: <http://www.agricultura.gov.br>Accessed on: December 10th, 2010.

NELSON, R. R.;Winter, S. G. (1977) In search of useful theory of innovation. Research Policy [S.I.],6, 36-76.

NELSON, R. R.; Winter, S., G. (2005) Uma teoria evolucionária da mudança econômica. Campinas: Unicamp.

ODUM, E. P. (197I) Fundamentos de ecologia. Trad. Antonio Manuel de Azevedo Gomes. 4th ed. Fund. Calouste Gulbenkian, Lisboa.

OLIVEIRA, L. (2008) Sociologia da Inovação: a construção social das técnicas e dos mercados. Celta Editora, Lisboa.

PORTOCARRERO, M. A.; Kososki, A. R. (2009) Alimentos seguros - uma política de governo. In: Brasil. Ministério da Agricultura, Pecuária e Abastecimento. Produção integrada no Brasil:agropecuária sustentável, alimentos seguros. Mapa/ ACS, Brasília.

ROBERTS, B. H. (2004) The application of industrial ecology principles and planning guidelines for the development of eco-industrial parks: an Australian case study. Journal of Cleaner Production. I2, 997-1010.
SCHUMPETER, J.A. (196I) Capitalismo, socialismo e democracia. Rio de Janeiro: Editora Fundo de Cultura.

SENAI.RS. (2003) Implementação de Programas de Produção mais Limpa. Porto Alegre, Centro Nacional de Tecnologias Limpas. SENAI-RS/ UNIDO/INEP.

SPETH, J. G. (1992) The transition to a sustainable society. Proceedings of the National Academy of Sciences of the United States. pp. 870-872.

TIBBS, H. (2004) Industrial Ecology. an environmental agenda for industry. global business network. Available at: http:// www.bfi.org/pdf/gbn_ecology.pdf. Accessed on Sept 10th 2004.

TONELLI, D. F.; Nogueira, E.a.t.; Oliveira, V.a.r.; De Benedicto, G.c. (20I2). Integrated production systems under the sustainable innovation perspective. African Journal of Business Management.6 (I4), 476I-4767.

VEIGA, José Eli da. (2010) Indicadores de sustentabilidade. Estud.av. [online], 24(68), 39-52.

VIZEU, Fábio. (2005) Ação comunicativa e estudos organizacionais. Revista de Administração de Empresas. 5(44), 10-25.

WACKERNAGEL, M.; Rees, W.(1996) Our ecological foot-

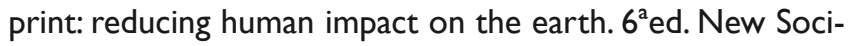
etyPublishers, Canada.

ZAMBOLIM, L. (2003) Produção integrada de café.Viçosa: Universidade Federal de Viçosa. 